\title{
Arsenic Contamination in Soil and Sediment in India: Sources, Effects, and Remediation
}

\author{
Anamika Shrivastava • Devanita Ghosh • \\ Ayusman Dash $\cdot$ Suatapa Bose
}

Published online: 24 March 2015

(C) Springer International Publishing AG 2015

\begin{abstract}
Arsenic contamination is turning out to be a major problem these days with its area coverage and the number of people affected directly or indirectly. Now, the level of the contaminant has spread over the soil and sediments from groundwater and other natural sources. Arsenic poisoning in groundwater events is familiar to the world, but the consequences of soil contamination are still unrevealed to the community, specially the people of contaminated counties. Arsenic is a serious instantaneous concern for the people and other life forms regarding the poisoning through crops and vegetables. Many remediation technologies that mainly include physical, chemical, and a few biological methods have been evolved with time to check its effects. The physical and chemical methods for this purpose are often inefficient and/or very expensive, mainly limited to application in aqueous systems, and produce toxic sludge, which again becomes a matter of concern. But bioremediation relies on the fact that biological
\end{abstract}

This article is part of the Topical Collection on Land Pollution

Anamika Shrivastava and Devanita Ghosh contributed equally to this work.

A. Shrivastava $\cdot$ S. Bose $(\bowtie)$

Earth and Environmental Science Research Laboratory, Department of Earth Sciences, Indian Institute of Science Education and Research

Kolkata, Mohanpur, Nadia, West Bengal 741246, India

e-mail: sutapa.bose@iiserkol.ac.in

S. Bose

e-mail: sutaparai@gmail.com

D. Ghosh • A. Dash

Department of Biological Sciences, Indian Institute of Science

Education and Research Kolkata, Mohanpur, Nadia, West

Bengal 741246, India

D. Ghosh

Department of Thematic Studies-Environmental Change, Linköping University, 58183 Linköping, Sweden organisms have the ability to degrade, detoxify, and even accumulate harmful chemicals and offers attractive perspectives for biomonitoring (via biosensors), treatment of wastewater, and the recycling of polluted soils.

Keywords Arsenic · Soil contamination · Toxicity · Bioremediation

\section{Introduction}

Arsenic (As) is one of the toxic compounds which pose a high risk to large human populations. Although it had been historically used as a drug to treat skin infections, and beautification, it was also used for human murder [1,34]. The contamination of arsenic in South Asian groundwater aquifers was first reported in the mid-1990s [13], and since then, a lot of work had been done for the past two decades. The utilization of these groundwater sources for irrigation and for drinking affected the various forms of life including humans, cattle, and crops [108••, 109••, 111], even causing death [61]. Earlier reports had shown that more than 200 million people across 70 countries are affected from As-contaminated groundwater [117, 118]. Yu et al. [135] found that per year there will be 1.2 million cases of health manifestations in Bangladesh only due to arsenic poisoning.

The riverine deposits of Bengal Delta Plains (BDP) formed the fertile plains of the three rivers Ganges Brahmaputra, and Mehgna. From the western to the northeastern borders of BDP, it have the Indian Plate, Chota Nagpur Plateau, Shilong Plateau, and Naga Lusai orogenic belt, making them intensely neotectonic [110]. The sediment deposition in these regions is also influenced by the regional vegetation and climate. Thus, the sources and distribution of As in these plains are largely controlled by the distribution of organic matter, oxic-anoxic conditions, and indigenous microbial flora $[9,36,48 \bullet, 53$, 
62]. The organic content of the soil had always been considered as an important component of the global carbon pool [71]. Two different types of sedimentary depositions are found in the BDP region. The first type is the gray micaceous Holocene sand depositions which are mainly linked with shallow aquifers, contaminated with high levels of As, known as gray sand aquifers (GSA) [5]. The second type is the brown sand aquifers. These are deep Pleistocene depositions, which, though vulnerable to As contamination, are considered safe for the time as the As levels are $<50 \mu \mathrm{g} / 1$ [18, 19, 100, 101]. The release of As is, however, a more complex process and involves many different parameters. Thus, a combined multidisciplinary study is needed including microbiological, geochemical, hydrological, and mineralogical approaches to identify the major factors controlling these processes in the BDP regions. However, many such large-scale studies had been done till date by many research groups across the globe, in finding out the source, distribution, and remediation ways to solve this problem, resulting in a large and growing literature. This review gives a brief overview of these works, covering most of the studies reported in the past 5 years, focusing on characteristics, As toxicity, sources and distribution of As, factors affecting As availability and mobility, factors affecting As transformation, effect of As on living forms, awareness, role of NGOs, and remediation.

\section{Characteristics}

\section{Physical Characteristics}

Arsenic (As) as a metalloid has three allotropes, gray, yellow, and black [89]. Naturally found arsenic has one stable isotope ${ }^{75}$ As [47]. However, many other isotopes have been synthesized. The compounds of As are similar to those of phosphorus $(\mathrm{P})$, and they belong to the same group in the periodic table. Arsenic occurs primarily in two oxidation states, the trivalent state arsenite As(III) and the pentavalent state arsenate $\mathrm{As}(\mathrm{V})$. Other than these, As is also present in -3 state in arsenides which are alloy-like intermetallic compounds.

\section{Forms of Arsenic in Soil}

Arsenic is present in soil in inorganic and organic forms. The inorganic forms of arsenic are more prevalent than the organic forms. The inorganic components majorly include the mineral forms, whereas the organic arsenic form is mostly found in living organisms due to arsenic consumption.

\section{Inorganic Forms}

The major concentration of soil As is present in mineral forms. Arsenic has more than 300 mineral forms, including arsenates, sulfides, sulfosalts, arsenites, arsenides, native elements, and metal alloys. The major mineral forms of As are detailed in Table 1. Among these, sulfide (e.g., arsenopyrite, pyrite, loellingite, realgar) and arsenate minerals (e.g., scorodite, beudantite, yukonite) are the most common soil-bound mineral forms $[72,112]$. The other minerals are generated during weathering.

\section{Organoarsenic Compounds}

Inorganic arsenic, when it enters the food chain, gets methylated and forms less toxic organic forms like monomethylarsine (MMA), dimethylarsine (DMA), and trimethylarsine (TMA; Fig. 1; [72]). Other than these, many other organic forms were developed during World War I like lewisite, adamsite, and cacodylic acid [41, 50, 115]. Some forms of organic arsenic, such as arsenobetaine or arsenocholine, are found in seafood [61].

\section{Arsenic Toxicity}

The toxicity of various forms of arsenic strongly depends on their oxidative states and chemical structures [83] The inorganic forms of As present in soil, when taken up and transported through the food chain, turn out to be toxic, affecting various life forms. Among the two oxidation states As(III) and $\mathrm{As}(\mathrm{V})$, the arsenite form $\mathrm{As}(\mathrm{V})$ is less toxic and mostly

Table 1 Major mineral forms of Arsenic

\begin{tabular}{lll}
\hline Mineral group & Mineral name & Formula \\
\hline Oxide of arsenite & Arsenolite & $\mathrm{As}_{2} \mathrm{O}_{3}$ \\
& Claudetite & $\mathrm{As}_{2} \mathrm{O}_{3}$ \\
Oxide of arsenate & $\begin{array}{c}\text { Arsenic } \\
\text { pentoxide }\end{array}$ & $\mathrm{As}_{2} \mathrm{O}_{5}$ \\
Fe-arsenate & Arseniosiderite & $\mathrm{Ca}_{2} \mathrm{Fe}_{3} \mathrm{O}_{2}\left(\mathrm{AsO}_{4}\right)_{3} \cdot 3 \mathrm{H}_{2} \mathrm{O}$ \\
& Parasymplesite & $\mathrm{Fe}_{3}\left(\mathrm{AsO}_{4}\right)_{2} \cdot 8 \mathrm{H}_{2} \mathrm{O}$ \\
& Pharmacosiderite & $\mathrm{K}\left[\mathrm{Fe}_{4}\left(\mathrm{OH}_{4}\right)_{4}\left(\mathrm{AsO}_{4}\right)_{3}\right] \cdot 6.5 \mathrm{H}_{2} \mathrm{O}$ \\
& Scorodite & $\mathrm{FeAsO}_{4} \cdot 2 \mathrm{H}_{2} \mathrm{O}$ \\
& Symplesite & $\mathrm{Fe}_{3}\left(\mathrm{AsO}_{4}\right)_{2} \cdot 8 \mathrm{H}_{2} \mathrm{O}$ \\
& Yukonite & $\mathrm{Ca}_{7} \mathrm{Fe}_{12}\left(\mathrm{AsO}_{4}\right)_{10}(\mathrm{OH})_{20} \cdot 15 \mathrm{H}_{2} \mathrm{O}$ \\
Fe sulfoarsenates & Beudantite & $\mathrm{PbFe}_{3}\left(\mathrm{AsO}_{4}\right)\left(\mathrm{SO}_{4}\right)(\mathrm{OH})_{6}$ \\
& Tooeleite & $\mathrm{Fe}_{6}\left(\mathrm{AsO}_{4}\right)_{4}\left(\mathrm{SO}_{4}\right)(\mathrm{OH})_{4} \cdot 4 \mathrm{H}_{2} \mathrm{O}$ \\
& Zýkaite & $\mathrm{Fe}_{4}\left(\mathrm{AsO}_{4}\right)_{3}\left(\mathrm{SO}_{4}\right)(\mathrm{OH}) \cdot 15 \mathrm{H}_{2} \mathrm{O}$ \\
Ca-Mg arsenates & Hörnesite & $\mathrm{Mg}_{3}\left(\mathrm{AsO}_{4}\right)_{2} \cdot 8 \mathrm{H}_{2} \mathrm{O}$ \\
& Pharmacolite & $\mathrm{Ca}\left(\mathrm{HAsO}_{4}\right)_{2} \cdot 2 \mathrm{H}_{2} \mathrm{O}$ \\
Other metal & Annabergite & $\mathrm{Ni}_{3}\left(\mathrm{AsO}_{4}\right)_{2} \cdot 8 \mathrm{H}_{2} \mathrm{O}$ \\
arsenates & Erythrite & $\mathrm{Co}_{3}\left(\mathrm{AsO}_{4}\right)_{2} \cdot 8 \mathrm{H}_{2} \mathrm{O}$ \\
& Köttigite & $\mathrm{Zn}_{3}\left(\mathrm{AsO}_{4}\right)_{2} \cdot 8 \mathrm{H}_{2} \mathrm{O}$ \\
& Mimetite & $\mathrm{Pb}_{5}\left(\mathrm{AsO}_{4}\right)_{3} \mathrm{Cl}$ \\
\hline
\end{tabular}




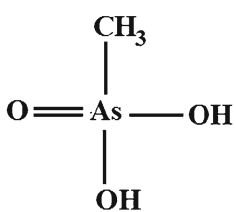

Monomethyl Arsine

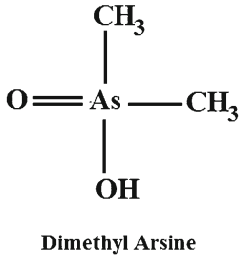

Dimethyl Arsine

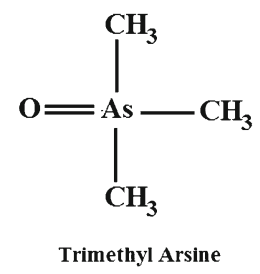

Trimethyl Arsine
Fig. 1 Major organoarsenic compounds

present in immobile mineral forms, whereas the As(III) form is more toxic and gets mobilized into water and enters living cells. Thus, the lethal dose $\left(\mathrm{LD}_{50}\right)$ of $\mathrm{As}(\mathrm{III})$ is also very less $(15-42 \mathrm{mg} / \mathrm{kg})$ compared to As(V) $(20-800 \mathrm{mg} / \mathrm{kg})$ [69]. As(III) binds with the sulfahydryl group of proteins, causing various clinical manifestations discussed later.

Arsenic, unlike other heavy metals like mercury $(\mathrm{Hg})$ and lead $(\mathrm{Pb})$, shows greater toxicity in inorganic forms than in organic forms. Among the organic arsenic forms, MMA and DMA are more toxic than TMA. Thus, the $\mathrm{LD}_{50}$ value for MMA $(1.8 \mathrm{~g} / \mathrm{kg})$ and DMA $(1.2 \mathrm{~g} / \mathrm{kg})$ is lower than that of TMA (10 g/kg; [83]).

\section{Sources and Distribution of Arsenic}

The prevalent form of arsenic, which is found to contaminate aquifers around the globe, is the one that is present naturally in the environment $[104,111]$. A variety of studies have been done over the past few decades to track factors which control As mobilization which ends up in groundwater, but these studies are debated till date $[31,54,84,97,104]$. One of the wellaccepted mechanisms states that release of As occurs when Fe oxides are reductively dissolved, an effect prevalent in sedimentary environments [14-16, 31, 39, 87, 88, 97, 104, 114].

The amount of arsenic in the groundwater of Bengal Delta Plain (West Bengal, India and Bangladesh) ranges from 50 to $3200 \mu \mathrm{g} / \mathrm{l}$, a value much greater than national drinking water standards which is $50 \mu \mathrm{g} / \mathrm{l}$ for India and Bangladesh and also surpasses the level set by WHO which is $10 \mu \mathrm{g} / 1[14-16,130]$.

Arsenic can be introduced in the environment either by natural processes (such as during atmospheric emissions or when naturally occurring minerals rich in arsenic are desorbed and dissolved) or by anthropogenic actions (such as mining, combustion of fossil fuels, metal extraction processes, timber preservatives, etc.) [14-16]. Broken-down grains rich in iron and arsenic adsorbed authigenic secondary oxide/hydroxide precipitates, termed as arsenic traps, might be one of the reasons of high arsenic occurrence in groundwater of BDP [14-16, 37, 80, 81]. Fe(III) present on the surface of BDP sediments may adsorb $\mathrm{Fe}(\mathrm{II})$ during iron oxide reduction. $\mathrm{Fe}(\mathrm{II})$, thus adsorbed, reduces $\mathrm{As}(\mathrm{V})$ to $\mathrm{As}(\mathrm{III})$. This reaction is responsible for the entry of toxic and labile As(III) in groundwater of BDP $[14,15]$.
Arsine is a very toxic gaseous As-containing compound $[32,72]$ formed in a highly reducing environment $[72,106]$. A decrease in $\mathrm{pH}$ favors arsine formation. In anoxic conditions, arsine is liberated from marshy soil and swampy surfaces along with monomethylarsine, dimethylarsine, and trimethylarsine $[38,72]$. Oxidation leads to conversion of such gases to aqueous phases of $\mathrm{As}(\mathrm{V})$-bearing compounds $[72,122,123]$.

In the atmosphere, As is prominently present as particles. Volcanic eruptions, wind mobilization, marine aerosols, and industrial exhausts give rise to As in the atmosphere. These particles settle on the ground when fossil fuels are burnt or when smelters are used and are termed as wet or dry deposition $[72,96]$. Wet deposition is that portion of atmospheric As which is dissolved in rainwater [72].

A low concentration of As is seen in alluvial sands of Aspolluted aquifers in BDP (less than $10 \mathrm{mg} / \mathrm{kg}$; [13, 72]). Weathering of As-bearing minerals leads to deposition of As in peaty, bog, acid sulfate, and various other natural soils. Average As content in such soils is less than $100 \mathrm{mg} / \mathrm{kg}$. Industrial contaminants lead to the highest levels of As deposition in sediments and soils which may soar up to several thousands of milligrams per kilogram [72]. Fly ash produced by coal combustion leads to As deposition in the Indian subcontinent $[72,91]$.

\section{Geogenic Arsenic Distribution Across India}

Weathering of the Himalayas leads to development of aquifers in sands settled on Pleistocene sediments. Sand aquifers are separated from overlying silts rich in organic matter by a palaeosol rich in clay. Arsenic-contaminated groundwater intersects boreholes containing gray sands which have undergone reductive dissolution. Sands present at greater depths become As deficient as clay-rich palaeosol separates organic matter necessary for reductive dissolution from the sands [103]. Flow of groundwater leads to frontal movement of redox and dissolved organic matter zones which in turn is thought to cause As discharge from deeper sands contained in such boreholes $[62,63,85]$. This model proposes the likelihood of As pollution caused by the presence of organic matter and sedimentary structure of aquifers [27, 29, 72].

In India, parts of many states have been identified as As contaminated in the case of soil and sediments, which are shown in Fig. 2 [25, 26, 91, 97, 106, 115, 116]. Arsenic mobilization in the Bengal Basin can occur by discharge of arsenic into alluvial sediments by oxidation of arsenic-containing pyrite [74, 75, 99], displacement of anions of As present in aquifer sedimentary minerals by phosphate anions used in fertilizers which are applied on the soil surface $[5,6,100$, 101], and discharge of arsenic in anoxic conditions by reduction of iron oxyhydroxide during sediment burial [14-16, 80, $81,87,88,100,101]$. 


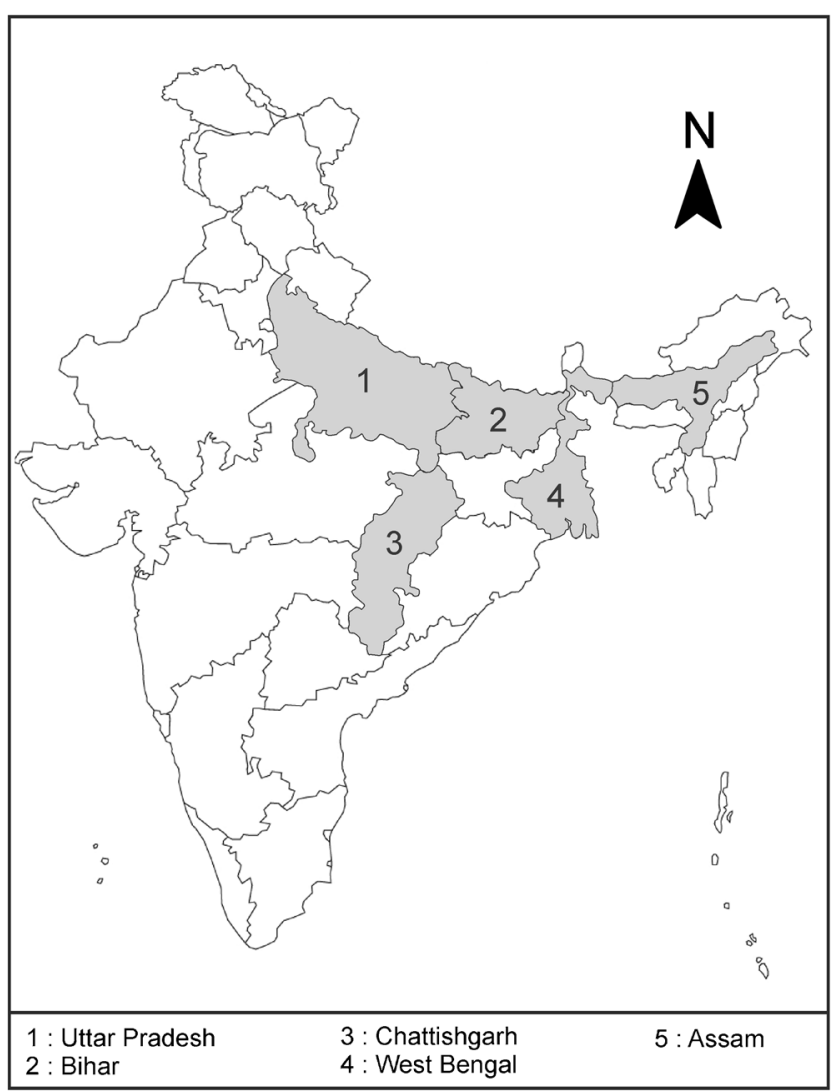

Fig. 2 Map of India showing states with As contamination in soil and sediments

\section{Factors Affecting Arsenic Availability and Mobility}

Bioavailability of As in soil is powerfully influenced by the chemical and physical characteristics of soils together with the character of minerals and clay content, organic matter, texture, $\mathrm{pH}$ and Eh, cation-exchange capability (CEC), and presence and concentration of oxides and hydroxides of metals, Al, Mn, etc. $[62,63,79,107 \bullet \bullet]$. Both As(III) and As(V) are powerfully adsorbed to hydrous oxides of metal, $\mathrm{Mn}$, and $\mathrm{Al}$ in acid soils whereas $\mathrm{Ca}$ oxides in alkaline soils to a lesser extent sorb anionic As species [132, 133].

Generally, fine-grained soils limit the quality of each As species than coarse-grained soils due to the presence of many minerals and organic constituents in them [30]. However, considering other aspects, such as if the concentrations of iron and aluminum hydrous oxides within the soil are low, As tends to be mobile. Additionally, the presence of a less-soluble mineral part and ionic forms that are powerfully adsorbed to soil particles or co-precipitated with different minerals are responsible for the reduction in bioavailability of arsenic from soil [79]. Apart from these factors, studies also recommend that bioavailability of arsenic in contaminated soils is also influenced by aging and sequestration [122].

The main sorbent for As(III) and As(V) is iron oxyhydroxides $(\mathrm{FeOOH})$. As(V) gets more strongly attached to iron oxyhydroxides as compared to As(III). Clay or clayey soil contains more FeOOH when compared to sandy soil, and therefore, clayey soil has more arsenic. Clayey soils are less toxic than sandy soils because in clayey soils arsenic is strongly adsorbed. In an anaerobic condition under microbial action or reduction conditions, arsenic bound to iron oxyhydroxides is freely released. There are bacteria that are capable of reducing $\mathrm{Fe}(\mathrm{III})$ as well as oxidizing $\mathrm{Fe}(\mathrm{II})$. It is also reported that reduction of arsenic from $\mathrm{V}$ to III state has taken place without desorption from iron oxyhydroxides [118, 119]. In aerobic conditions, iron oxyhydroxides become insoluble and therefore there is lesser release of arsenic. The arsenic and iron relation is dynamic in nature and plays an important role in aging of the paddy field. Amorphous iron oxides have strong affinity for arsenic.

Also in soils, as in water, the chemical behavior of As is in many ways similar to that of phosphorus $(\mathrm{P})$, especially in aerated systems, where $\mathrm{As}(\mathrm{V})$ ions generally resemble the orthophosphate ion closely [128]. However, under conditions normally encountered in soils, As is more mobile than $\mathrm{P}$ and unlike P can undergo changes in its valency [113-115]. Generally, As does not follow the typical behavior of other metal contaminants. For instance, it is highly soluble in neutral to alkaline $\mathrm{pH}$ (6.6-7.8) whereas most of the heavy metals are more mobile under acidic conditions. However, As can also be moderately soluble under acidic conditions. For this reason, its chemistry is more complex in soils than many other pollutants. Arsenic forms a variety of inorganic and organic compounds in soils [127] and is present as an inorganic species, either As(V) or As(III) [79]. The forms present in soils depend on the type and amounts of sorbing components of the soil, $\mathrm{pH}$, and redox potential. Under oxic soil conditions (Eh> $200 \mathrm{mV}$; pH 5-8), As is commonly present in the +5 oxidation state. However, As(III) is the predominant form under reducing conditions [77-79]. Both As(V) and As(III) species can undergo chemical and or microbial oxidation-reduction and methylation reactions in soils and sediments and can adsorb on hydrous oxides of Fe, Al, and Mn ([17]; Fig. 3). The most important natural attenuation process known for As(III) compounds is precipitation as As sulfide $\left(\mathrm{As}_{2} \mathrm{~S}_{3}\right)$. As(III) is more toxic and mobile in soils than $\mathrm{As}(\mathrm{V})$, and methylated species such as monomethylarsonic acid [MMAA, $\left.\mathrm{CH}_{3} \mathrm{AsO}(\mathrm{OH})_{2}\right]$ and dimethylarsinic acid [DMAA, $\left[\left(\mathrm{CH}_{3}\right)_{2} \mathrm{AsO}(\mathrm{OH})\right]$ are also mobile $[14,15]$. However, these methylated forms are volatile and unstable under oxidizing conditions and are cycled back into the soil environment in inorganic forms [34]. Ferric hydroxide $\left[\mathrm{Fe}(\mathrm{OH})_{3}\right]$ plays an important role in controlling the As concentration in soils. Both $\mathrm{As}(\mathrm{V})$ and $\mathrm{As}(\mathrm{III})$ are adsorbed onto the surface of $\mathrm{Fe}(\mathrm{OH})_{3}$, but the adsorption of $\mathrm{As}(\mathrm{V})$ is much higher than that of As(III) [14, 15]. In general, highly oxic soils sorb three times more As(V) than soils containing small amounts of oxic minerals $[113,114]$. The presence of iron, aluminum, and calcium compounds is the most 
Fig. 3 Arsenic transformation in soil (modified after Bhumbla and Keefer [17]

\begin{tabular}{|c|c|c|c|}
\hline \multirow{2}{*}{\multicolumn{2}{|c|}{$\begin{array}{ll}\text { Arsenate } \longrightarrow & \text { Adsorption on } \\
\text { hydrous oxides }\end{array}$}} & Arsenate & Arsenite \\
\hline & & $\begin{array}{l}\mathrm{HAsO}_{4}^{2-} \\
\mathrm{HAsO}_{4}^{-}\end{array}$ & $\mathrm{AsO}_{3}^{2-}$ \\
\hline $\begin{array}{l}\text { Arsenite } \\
\quad \text { Microbial }\end{array}$ & Arsenopyrite & $\begin{array}{l}\text { Monomethyl } \\
\text { Arsonic Acid }\end{array}$ & $\begin{array}{l}\text { Dimethyl } \\
\text { Arsinic Acid }\end{array}$ \\
\hline $\begin{array}{l}\text { Imethylation } \\
\text { Monomethyl } \\
\text { Arsonic Acid } \\
\square \text { Microbial }\end{array}$ & $\begin{array}{l}\text { (Fe, } \mathrm{Al}, \mathrm{Mn}) \text { and } \\
\text { precipitation }\end{array}$ & $\begin{array}{c}\mathrm{O} \\
\mathrm{H}_{3} \mathrm{C}-\mathrm{As}-\mathrm{OH} \\
\mathrm{OH}\end{array}$ & $\begin{array}{c}\mathrm{O} \\
\stackrel{1}{\mathrm{H}_{3} \mathrm{C}-\mathrm{As}}-\mathrm{CH}_{3} \\
\mathrm{OH} \\
\end{array}$ \\
\hline $\begin{array}{l}\text { methylation } \\
\text { Dimethyl Arsinic }\end{array}$ & & $\begin{array}{l}\text { Dimethyl } \\
\text { Arsine }\end{array}$ & $\begin{array}{l}\text { Trimethyl } \\
\text { Arsine }\end{array}$ \\
\hline $\begin{array}{l}\text { Acid } \\
\text { Microbial } \\
\text { methylation }\end{array}$ & 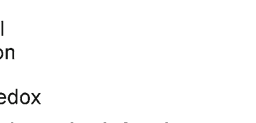 & $\begin{array}{c}\mathrm{CH}_{3} \\
\mathrm{l} \\
\mathrm{H}_{3} \mathrm{C}-\mathrm{As}-\mathrm{H}\end{array}$ & $\begin{array}{c}\mathrm{CH}_{3} \\
\mathrm{l} \\
\mathrm{H}_{3} \mathrm{C}-\mathrm{As}-\mathrm{CH}_{3} \\
\end{array}$ \\
\hline Dimethyl Arsine & rimethyl Arsine & Arsenopyrite & $\begin{array}{l}\mathrm{As}_{2} \mathrm{~S}_{3}, \mathrm{As}_{3} \mathrm{~S}_{4} \\
\mathrm{FeAsS}\end{array}$ \\
\hline
\end{tabular}

important factor in controlling the fixation in soil [18]. The sorptive capacity of a soil for an ion is a function of its surface area and hence its clay content; this explains why As is more mobile in sandy soil than fine-textured soils [128].

\section{Factors Affecting the Arsenic Transformation}

\section{Soil Factor}

Within the soil, the nature and proportion of the constituents determine the arsenic behavior. It is seen that inorganic arsenic species have high affinity for hydrous oxides of $\mathrm{Fe}, \mathrm{Mn}$, and $\mathrm{Al}$ in acid soils whereas calcium oxides in alkaline soils to a lesser extent adsorb anionic As species [132, 133]. And thus, the anionic species are more bioavailable to crops grown in alkaline soils [44]. However, if the concentrations of iron and aluminum hydrous oxides in the soil are low, As tends to be mobile. Reduced bioavailability in soil is thought to be primarily a function of the presence of a less-soluble mineral phase and ionic forms that are strongly adsorbed to soil particles or co-precipitated with other minerals. Factors that influence the adsorption capacity of soils influence the bioavailability and subsequent mobility of As in soils. The studies suggest that bioavailability in contaminated soils is also influenced by aging and sequestration $[122,123]$. Soil $\mathrm{pH}$ was the most important soil property affecting the decrease in bioaccessibility on aging [134].

\section{Adsorption and Desorption}

Adsorption and desorption processes are the principal factors affecting the transport, degradation, and biological availability of compounds in soil [113]. Hayes and Traina [56] reported that $\mathrm{As}(\mathrm{V})$ was strongly adsorbed on metal oxides and formed relatively insoluble precipitates with $\mathrm{Fe}$ and therefore became less bioavailable. They also reported that, at higher $\mathrm{pH}, \mathrm{As}(\mathrm{III})$ sorbed more weakly than $\mathrm{As}(\mathrm{V})$ to metal oxides and therefore became bioavailable [79, 85]. In summary, soil conditions that promote precipitation or adsorption also tend to reduce the mobility and bioavailability of As. Numerous studies have demonstrated that the plant uptake of As is greatly influenced by its form in soil [22, 24, 77, 78, 121]. The presence of other ions such as $\mathrm{Fe}$ and $\mathrm{P}$ also affects As availability and phytotoxicity [45].

\section{Microbial Processes}

The microbial flora of a niche majorly influences the oxidation status and availability of As. Though microbes are widely reported for oxidation, reduction, methylation, and demethylation of As, the oxidation of reduced As species has been less widely studied except a few studies [23, 48••, 90] than the processes of microbial reduction of As.

Microbial methylation of As by common bacterial species in soil has been reported by a number of authors [12]. Methanogenic bacterial genera had been widely reported for methylation of As to different forms such as MMA and DMA $[82,98]$. However, DMA is very unstable and quickly oxidizes under aerobic conditions [34]. The methyl forms of As undergo volatilization and thus have more toxicity than the nonmethylated forms [12].

\section{Effect of Arsenic on Living Forms}

Arsenic(V) is a chemical analog of phosphate that can disrupt at least some phosphate-dependent aspects of metabolism in all living forms. Arsenic(V) can be translocated across cellular membranes by phosphate transport proteins, leading to imbalances in phosphate supply [42]. In general, during phosphorylation reactions, arsenic $(\mathrm{V})$ competes with phosphate and 
forms unstable adducts. For example, during the formation of ATP, arsenic binds to ADP forming As(V)-ADP, and hence, the cycle will be a futile one; this decreases the ability of the cell to produce ATP and carry out their metabolism. Oxidative carbon metabolism, amino acid and protein relationships, and nitrogen and sulfur assimilation pathways are also impacted by arsenic exposure [42]. The effects of arsenic on different living forms are discussed in the following paragraphs.

\section{Effects of Arsenic on Plants}

Arsenic, being a non-essential element, is not required for the growth of living organisms, with the exception of a newly discovered bacterium that replaces phosphorus with As for many cellular functions [131]. There are cases where the terrestrial plants may accumulate As by root uptake from soil or by absorption of airborne As deposited on the leaves [125]. In general, plants growing in natural soil contain low levels of As $(<3.6 \mathrm{mg} / \mathrm{kg}$ [46]). At a higher concentration, arsenic is toxic to most plants. Arsenate is the dominant species in soils, and its similarity to phosphate allows it to compete for the same uptake carriers in the root plasmalemma. It interferes with metabolic processes and inhibits plant growth and development through arsenic-induced phytotoxicity [77, 78].

The toxicity symptoms may include inhibition of seed germination [2], decrease in plant height [2, 24, 67, 77, 78], depressed tillering [70], reduction in root growth and some necrosis (unprogrammed cell/living tissue death; [2]), decrease in shoot growth [33], and lower fruit and grain yield $[2,3,24,70]$ and sometimes lead to death $[10,77,78,136]$ discolored and stunted roots, withered and yellow leaves [74], and reductions in chlorophyll and protein contents, and in photosynthetic capacity [77, 78]. However, little is known about the effect of arsenic on photosynthesis, the basis of the plant bio-chemical system. As almost all of the abovementioned adverse physiological and agronomical effects of arsenic are related to the basic photochemical reaction in rice plants $[135,136]$, photosynthesis, it is important to measure chlorophyll $\mathrm{a}$ and $\mathrm{b}$, the major photosynthetic pigments, contents in rice leaves to justify their correlations with rice growth and yield.

Paddy rice is more susceptible to As accumulation than other cereals because of the high mobility of arsenic under a flooded condition [73]. A previous study performed in wheat plants reported a decrease in the amylolytic activity due to arsenic toxicity. Pteris vittata commonly known as brake fern is the first species known as a hyperaccumulator for As. Brake fern can also hyperaccumulate arsenic, deriving from insoluble forms up to three to six times greater than the As concentration in soil, whereas the bioaccumulation of arsenic in aquatic organisms occurs primarily in algae and lower invertebrates $[58,73]$.

\section{Effect on Human Health}

The risk of human exposure to soil As has greatly increased in the last two decades mainly due to the expansion of residential areas into former agricultural land [76]. This has affected human health very adversely. Chronic exposure to As causes many clinical manifestations of which cutaneous lesions are the highest reported $[35,130]$. These arsenic-associated clinical manifestations include melanosis (hyperpigmentation), keratosis, and leukomelanosis (hypopigmentation). Other than causing superficial cuticular diseases, As is also a well-known carcinogen, causing skin, lung, bladder, liver, and kidney cancers $[66,86]$. The other health manifestations include carotid atherosclerosis $[65,75]$, ischemic heart disease [4], and impaired cognitive abilities and motor functions [52]. Arsenic also affects the hormonal regulations via the retinoic acid, thyroid hormone, and estrogen receptors [11].

\section{Effect of Arsenic on Animals}

Arsenic-contaminated food and water are the channels through which this metalloid enters a mammalian body. There are instances where derivatives of arsonic acid are fed to domestic livestock to enhance body growth and inhibit any oncoming disease [40]. Arsenic poisoning in homeothermal animals is implicated by high mortality in the course of 2-3 days [40, 84, 105]. Other symptoms of arsenic poisoning include abdominal pain, weakness, salivation, nausea, and death in the ultimate scenario. Autopsy of such affected individuals show a reddened edematous gastric and intestinal mucosa, yellowing of the liver, and edema in the lungs. Other effects include necrosis of mucosal epithelia and degeneration of the renal tube and gastrointestinal capillaries. Prolonged exposure to arsenic contamination leads to depression, dehydration, anorexia, frequent urination, and imbalance in body temperature [40, 84, 105]. Cutaneous arsenic exposure leads to drying up and deadening of the skin $[40,84]$. Arsenic inhalation in rodents led to nasal flow discharge and eye irritation [40, 60].

Lab animals showed symptoms of PNS abnormalities, anemia, leukopenia, melanosis, cardiac malfunction, and liver damage. Surprisingly, these symptoms vanished when exposure got refrained [40, 94, 95]. Acute and sub-acute symptoms demarcate arsenic poisoning whereas chronic poisoning is rare [40, 84, 132]. This is because of immediate follow-up of detoxification and excretion processes [40, 132]. External uptaking of arsenic compounds affects the spleen, kidney, liver, and lungs; these compounds can then mobilize to ectodermal tissues such as nails and hair as these tissues are rich in sulfur-containing proteins [40].

Domestic animals are also widely affected by arsenic poisoning. A classic example is the death of around a hundred cattle due to overdose of arsenic trioxide which was applied externally to prevent lice infestation. Autopsy reports 
suggested subcutaneous edema and hemorrhage in the intestine, kidney, and epidermis [40, 102]. In a study in Bangladesh, cattle poisoned with arsenicals showed symptoms of restlessness, diarrhea, instability in walking, convulsions, panting, and salivation [40]. Such symptoms were followed by their death within the next $12-36 \mathrm{~h}$. Autopsy reports showed hemorrhage in the submucosa of the gastrointestinal tract [40] and tissue deposits greater than $10 \mathrm{mg} / \mathrm{kg}$ fresh weight of the liver and kidney [40, 120]. It is presumed that cattle have an enhanced attraction towards weeds sprayed with an arsenic-containing weed killer because of the salty taste of arsenic compounds [40, 105].

\section{Remediation}

Arsenic present in different forms in soil and sediments is the major contaminant of groundwater in the Indo-Gangetic plain. Since a large population is dependent on groundwater as source of potable drinking water, remediation or treatment of this water before consumption is one of the major requirements. Many remediation technologies have been developed for the removing of arsenic from groundwater mainly. These mostly include the physical- or chemical-based methods and a few bioremediation methods as described below.

Physical or Chemical Remediation

\section{Oxidation}

Addition of chemical oxidants causes conversion of toxic mobile As(III) to a form less toxic and immobile As(V). As(III) can be oxidized by a number of chemicals such as gaseous chlorine, permanganate, hydrogen peroxide, and Fenton's reagent $\left(\mathrm{H}_{2} \mathrm{O}_{2} / \mathrm{Fe}^{2+}\right)$ [68]. Direct ultraviolet (UV) radiationbased oxidation of arsenite in the presence of sulfite as catalyte [49], or ferric iron [42, 43] or citrate (EAWAG, 1999), is also done.

\section{Precipitation}

The dissolved arsenic can be removed by forming lowsolubility solid minerals such as calcium arsenate [59]. The precipitate of such low-solubility solid minerals can be removed through sedimentation and filtration. Addition of coagulants causing floc formation can also be utilized to remove arsenic by co-precipitation. This is accompanied by filtration.

\section{Adsorption and Ion Exchange}

Minerals having a strong affinity for arsenic, such as iron and aluminum hydroxide, strongly adsorb arsenic ions onto their solid surfaces [49]. After sorption, water can be purified by gravity settling and filtration.

\section{Biological Remediation}

Although biological remediation is a slower process, it is more environment friendly [126]. Recent studies have shown that bioremediation of arsenic in soil can be accomplished using plants and different microbes [7, 8, 129].

\section{Bioremediation by Plants}

Phytoremediation is accomplished by using different types of green plants [36, 51]. The various mechanisms of phytoremediation are given below:

Phytoextraction Few species of plants, while growing on contaminated sediments, accumulate metal arsenic into their roots [20] and translocate them to the surface. The main limiting factors for phytoextraction are the following:

- Bioavailability of arsenic around the rhizosphere

- Rate of uptake of arsenic by roots

- Rate of loading of arsenic into xylem/translocation to shoots

- Cellular tolerance to arsenic

Phytostabilization Some plants decrease the volume of water percolating through the sediment matrix and thus act as a barrier, preventing contamination of soil [99]. Phytostabilization can also occur through sorption, complexation, or metal valence reduction and serves as a useful tool in mining land areas [99].

Rhizofiltration While capillary water is being absorbed through the root xylem, the heavy metals, if present in the water, are also being taken up. This process is called rhizofiltration. Rhizofiltration mainly functions in remediation of extracted groundwater, subsurface or surface water, and wastewater with low concentrations of contaminant.

Phytovolatilization Plants take up the contaminants from groundwater through their roots, pass them through xylem vessels and volatilize them, and release them during transpiration. This process is called phytovolatilization [57].

\section{Microbial Bioremediation}

Cost-effective and environment-friendly ways can be found using various bioremediation processes involving microbes. Microbial processes such as As oxidation and reduction, mobilizes and immobilizes through sorption, biomethylation, 
complexation, and can also bioremediate different forms of arsenic [21], among which microbial oxidation of arsenite $\mathrm{As}(\mathrm{III})$ to arsenate $\mathrm{As}(\mathrm{V})$ is predicted to be one of the most promising ways to immobilize the dissolved arsenic [48••, 90]. These processes are supported by in situ available organic carbon and other inorganic components like $\mathrm{Fe}, \mathrm{Mn}$, and $\mathrm{S}$ concentrations. The various methods of microbial bioremediation of arsenic are discussed in the following paragraphs.

Biostimulation The process of biostimulation includes introduction of stimulants into a system to induce the indigenous microbial flora to enhance their bioremediation mechanism [33]. These stimulants can be water, nutrients, oxygen, $\mathrm{S}$, etc. [1]. Many other stimulants like nitrogen $(\mathrm{N})$, phosphorus $(\mathrm{P})$, sodium acetate $\left(\mathrm{Na}-\mathrm{CH}_{3} \mathrm{COOH}\right)$, and ethanol had also been tested.

Bioaugmentation The process of bioaugmentation includes introduction of laboratory-tested microbial strains into an artificial system. In such process, small-scale laboratory-based researches of rates of bioremediation are tested, and then, the efficient groups of microbes are introduced to a large-scale system. Genetically engineered, highly efficient stains can also be developed and used. Recent studies on arseniteoxidizing bacteria in the Indian subcontinent give evidences of the presence of such microbes that can be isolated and utilized for bioaugmentation [48••].

\section{Awareness and Role of NGOs}

The presence of arsenic in groundwater was first detected in 1993, but the depth of the magnitude and the extent of the problem were not taken cared of till 1997. The detailed study for this was not performed thoroughly by many agencies involved due to the lack of testing [25, 26, 113]. In India many states including West Bengal, Jharkhand, Bihar, and Uttar Pradesh in the flood plain of Ganga River; Assam and Manipur in the flood plain of Brahamaputra and Imphal; and Rajnandgaon village in Chhattisgarh state have so far been identified in 2008 to be exposed to arsenic through drinking arsenic-contaminated groundwater [92, 93]. Many initiatives were taken that led to the development of strategies to reduce As exposure from drinking water. In this regard, both national and international agencies started working to provide safe drinking water to the affected rural population, by remediation of the As-contaminated groundwater, changing the sources of drinking water by targeting deeper safe aquifers, or supplying treated surface water [7, 8]. In the course, awareness-building measures suggested mainly include conducting sensitization workshops at state, district, block, and Gram Panchayat levels by the Public Health Engineering Department (PHED) of the state and imparting of training to local clubs, NGOs, etc.
Noticeably, all the efforts are being put on the groundwater arsenic contamination but not on the soil contamination that is proving to turn out to be the major source now.

Governmental organizations, NGOs, and research and international organizations are trying to mitigate the problem by providing various options like dug wells, pond sand filters, household As-removal filters, and rainwater harvesting. None of these options are found suitable and accepted by the people because of their limitations such as cost, maintenance, disposal of sludge, non-availability, etc. [53]. Use of surface water is also not suitable because it is highly polluted with pathogens, agrochemicals, and industrial wastes. Few community-based As-removal plants are installed by NGOs and international organizations in some highly As-affected areas. Supplies of drinking water from such large-scale As-removal or water treatment plants through pipelines in rural areas are costly and difficult.

\section{Measures to Reduce As Exposure}

In order to check the effects of arsenic, long-term actions are required from mining, metal smelting and refining, combustion of low-grade coal, pesticide use, and timber treatment. Most importantly, in these As affected with high groundwater arsenic, action is needed to reduce the intake of arsenic from drinking water and food $[64,130]$, which may include provision of safe drinking water, regular monitoring of the arsenic level in groundwater, awareness among dependents, designing and developing arsenic removal technologies, discriminating between high-arsenic and low-arsenic water sources by painting hand pumps in different colors (e.g., red and green) [124], or adapting sediment-coloring tools [63, 64]. In addition to these, monitor high-risk populations for early signs of arsenic poisoning, usually skin problems and other effects $[55$, 56].

\section{Conclusions}

Arsenic (As) is one of the toxic compounds present in soil in inorganic and organic forms and has been identified to pose a high risk to large human populations. The sources and distribution of As are largely controlled by many factors like the distribution of organic matter, oxic-anoxic conditions, indigenous microbial flora, etc. Arsenic can be introduced in the environment either by natural processes or by anthropogenic actions. The toxicity of various forms of arsenic strongly depends on their oxidative states and chemical structures.

The introduction of arsenic to the deeper sands of boreholes can be due to the frontal movement of redox and dissolved organic matter in the groundwater from shallow aquifers [28]. In soil, the bioavailability of As is mainly influenced by the 
chemical and physical characteristics of soils together with the character of minerals and clay content, organic matter, texture, $\mathrm{pH}$ and Eh, cation-exchange capability (CEC), and presence and concentration of oxides and hydroxides of metals, $\mathrm{Al}, \mathrm{Mn}$, etc.

The effects of $\operatorname{arsenic}(\mathrm{V})$ can be seen by its analogy with phosphate that can disrupt at least some phosphate-dependent aspects of metabolism in all living forms. It can also be translocated across cellular membranes by phosphate transport proteins, leading to imbalances in phosphate supply. In the case of plants, As is toxic at higher concentrations. It mainly interferes with metabolic processes and inhibits plant growth and development through arsenic-induced phytotoxicity. In the case of animals, the chronic exposure causes many clinical manifestations of which cutaneous lesions are the highest reported; arsenic is also a well-known carcinogen, causing skin, lung, bladder, liver, and kidney cancers.

Currently, the As present in soil and sediments in different forms is the major contaminant in the Indo-Gangetic plain due to a large population residing in the area. Thus, there is a need for a routine assessment of arsenic on a regular basis. Apart from that, the remediation or treatment measures in these areas are of major concern at this point. For this, governmental organizations, NGOs, and research and international organizations along with the participation of the local people are required considering the present scenario.

\section{Compliance with Ethics Guidelines}

Conflict of Interest Anamika Shrivastava, Devanita Ghosh, Ayusman Das, and Suatapa Bose declare that they have no conflict of interest.

Human and Animal Rights and Informed Consent This article does not contain any studies with human or animal subjects performed by any of the authors.

\section{References}

Papers of particular interest, published recently, have been highlighted as:

•• Of major importance

1. Abdulsalam S, Bugaje IM, Adefila SS, Ibrahim S. Comparison of biostimulation and bioaugmentation for remediation of soil contaminated with spent motor oil. Int J Environ Sci Technol. 2011;8: 187-94.

2. Abedin MJ, Cottep-Howells J, Meharg AA. Arsenic uptake and accumulation in rice (Oryza sativa L.) irrigated with contaminated water. Plant Soil. 2002;240:311-9.

3. Abedin MJ, Meharg AA. Relative toxicity of arsenite and arsenate on germination and early seedling growth of rice (Oryza sativa L.). Plant Soil. 2002;243:57-66.

4. Abhyankar LN, Jones MR, Guallar E, Navas-Acien A. Arsenic exposure and hypertension: a systematic review. Environ Health Perspect. 2012;120:494-500.
5. Acharyya SK, Lahiri S, Raymahashay BC, Bhowmik A. Arsenic toxicity of groundwater in parts of the Bengal Basin in India and Bangladesh: the role of Quaternary stratigraphy and Holocene sealevel fluctuation. Environ Geol. 2000;39:1127-37.

6. Acharyya SK, Chakraborty P, Lahiri S, Raymahashay BC, Guha $\mathrm{S}$, Bhowmik A. Arsenic poisoning in the Ganges delta. Nature. 1999;401:545-6.

7. Ahmed I, Hayat S, Pichtel J, editors. Heavy metal contamination of soil. Problems and remedies. Enfield: Science Publishers, Inc; 2005.

8. Ahmed MF, Ahuja S, Alauddin M, Hug SJ, Lloyd JR, Pfaff A, et al. Ensuring safe drinking water in Bangladesh. Science. 2006;314:1687-8.

9. Anwar HM, Yoshioka T, Konohira E, Akai J, Freitas MC, Tareq SM. Sources of organic carbon and depositional environment in the Bengal delta plain sediments during the Holocene period. Limnology. 2010;11:133-42.

10. Baker S, Barrentine WL, Bowmaan DH, Haawthorne WL, Pettiet JV. Crop response and arsenic uptake following soil incorporation of MSMA. Weed Sci. 1976;24:322-6.

11. Barr FD, Krohmer LJ, Hamilton JW, Sheldon LA. Disruption of histone modification and CARM1 recruitment by arsenic represses transcription at glucocorticoid receptor-regulated promoters. PLoS One. 2009;4(8):e6766. doi:10.1371/journal.pone. 0006766.

12. Bentley R, Chasteen TG. Arsenic curiosa and humanity. J Chem Educ. 2002;7:51-60.

13. BGS \& DPHE. Arsenic contamination of groundwater in Bangladesh (four volumes). BGS technical report WC/00/19, British Geological Survey, Keyworth; 2001.

14. Bhattacharya P, Chatterjee D, Jacks G. Occurrence of arseniccontaminated groundwater in alluvial aquifers from delta plains, eastern India: options for safe drinking water supply. J Water Resour Dev. 1997;13:79-92.

15. Bhattacharya P, Jacks G, Frisbie SH, Smith E, Naidu R, Sarkar B. Arsenic in the environment: a global perspective. In: Sarkar B, editor. Handbook of heavy metals in the environment. New York: Dekker; 2002. p. 147-215.

16. Bhattacharyya R, Chatterjee D, Nath B, Jana J, Jacks G, Vahter M. High arsenic groundwater: mobilization, metabolism and mitigation - an overview in the Bengal Delta Plain. Mol Cell Biochem. 2003;253:347-55.

17. Bhumbla DK, Keefer RF. Arsenic mobilization and bioavailability in soils. In: Nriagu JO, editor. Arsenic in the environment, part 1. New York: Cycling and Characterization. Wiley; 1994. p. 51-82.

18. Bissen M, Frimmel FH. Arsenic: a review. Part I: occurrence, toxicity, speciation, mobility. Acta Hydrochim Hydrobiol. 2003;31:9-18.

19. Biswas A, Nath B, Bhattacharya P, Halder D, Kundu AK, Mandal $\mathrm{U}$, et al. Hydrogeochemical contrast between brown and grey sand aquifers in shallow depth of Bengal Basin: consequences for sustainable drinking water supply. Sci Total Environ. 2012;431:40212.

20. Brennan MA, Shelley ML. A model of the uptake, translocation, and accumulation of lead $(\mathrm{Pb})$ by maize for the purpose of phytoextraction. Ecol Eng. 1999;12:271-97.

21. Bundschuh J, Hollander H. In-situ remediation of arsenic contaminated sites. IWA Publishers; 2014.

22. Burló F, Guijarro I, Carbonell-Barrachina AA, Valero D, Martínez-Sánchez F. Arsenic species: effects on and accumulation by tomato plants. J Agric Food Chem. 1999;47:1247-53.

23. Camargo FA, Okeke BC, Bento FM, Frankenberger WT. In-vitro reduction of hexavalent chromium by a cell-free extract of Bacillus sp. ES 29 stimulated by $\mathrm{Cu}^{2+}$. Appl Microbiol Biotechnol. 2003;62:569-73. 
24. Carbonell-Barrachina AA, Burlo-Carbonell F, Mataix-Beneyto J. Arsenic uptake, distribution and accumulation in tomato plants: effect of arsenic on plant growth and yield. J Plant Nutr. 1995; 18: 1237-50.

25. CGWB. High incidence of arsenic in groundwater in West Bengal. Government of India: Central Ground Water Board, Ministry of Water Resources; 1999.

26. CGWB-Central Ground Water Board. Groundwater resources of Assam. Guwahati: CGWB, North East Region, Ministry of Water Resource; 2004.

27. Chakraborti D, Mukherjee S, Pati S, Sengupta MK, Rahman MM, Chowdhury UK, et al. Arsenic groundwater contamination in middle Ganga Plain, Bihar, India: a future danger. Environ Health Perspect. 2003;111:1194-201.

28. Chakraborty S, Nath B, Chatterjee D, et al. Retardation of arsenic transport by oxidized Holocene aquifer sediments of West Bengal, India. J Hydrol. 2014;518:460-3.

29. Chakraborti D, Rahman MM, Chowdhury UK, Paul K, Sengupta MK, Lodh D, et al. Arsenic calamity in the Indian subcontinent: what lessons have been learned? Talanta. 2002;58:3-22.

30. Chakraborti D, Basu GK, Biswas BK, Chowdhury UK, Rahman MM, Paul K, et al. Characterization of arsenic bearing sediments in Gangetic Delta of West Bengal-India. In: Chappell WR, Abernathy CO, Calderon RL, editors. Arsenic exposure and health effects. New York: Elsevier Science; 2001. p. 27-52.

31. Charlet L, Chakraborty S, Appelo CAJ, Roman-Ross G, Nath B, Ansari AA, et al. Chemodynamics of an As "hotspot" in a West Bengal aquifer: a field and reactive transport modeling study. Appl Geochem. 2007;22:1273-92.

32. Chauhan S, D'Cruz R, Fauqi S, Singh KK, Varma S, Singh M, et al. Chemical warfare agents. Environ Toxicol Pharmacol. 2008;26:113-22.

33. Couto MNPFS, Monteiro E, Vasconselous MTSD. Mesocosm trials of bioremediation of contaminated soil of a petroleum refinery: comparison of natural attenuation, biostimulation and bioaugmentation. Environ Sci Pollut Res. 2010;17(7):1339-46.

34. Cullen WR, Reimer KJ. Arsenic speciation in the environment. Chem Rev. 1989;89:713-64.

35. Das NK, Sengupta SR. Arsenicosis: diagnosis and treatment. Indian J Dermatol Venereol Leprol. 2008;74(6):571-81.

36. Datta R, Quispe MA, Dibyendu Sarkar D. Greenhouse study on the phytoremediation potential of vetiver grass, Chrysopogon zizanioides L., in arsenic-contaminated soils. Bull Environ Contam Toxicol. 2011;86:12-128.

37. Desbarats AJ, Koenig CEM, Pal T, et al. Groundwater flow dynamics and arsenic source characterization in an aquifer system of West Bengal, India. Water Res Resour Res. 2014;50:4974-5002.

38. Duker AA, Carranza EJM, Hale M. Arsenic geochemistry and health. Environ Int. 2005;31:631-41.

39. Eiche E, Neumann T, Berg M, Weinman B, van Geen A, Norra S, et al. Geochemical processes underlying a sharp contrast in groundwater arsenic concentrations in a village on the Red River delta, Vietnam. Appl Geochem. 2008;23:3143-54.

40. Eisler R. Arsenic hazards to fish, wildlife, and invertebrates: a synoptic review. Biol Rep. 1988;85:1-12.

41. Ellison HD. Handbook of chemical and biological warfare agents. CRC Press. ISBN 9780849314346; 2007.

42. Emett MT, Khoe GH. Photochemical oxidation of arsenic by oxygen and iron in acidic solutions. Water Res. 2001;35(3):649-56.

43. Finnegan PM, Chen W. Arsenic toxicity: the effects on plant metabolism. Front Physiol. 2012;3:182. doi:10.3389/fphys.2012. 00182.

44. Frost RR, Griffin RA. Effect of $\mathrm{pH}$ on adsorption of arsenic and selenium from landfill leachate by clay minerals. Soil Sci Soc Am J. 1977;41:53-7.
45. Fowler BA (editor). Biological and environmental effects of arsenic. Topics in Environmental Health, Elsevier Science Publisher, Amsterdam, New York, Oxford, Vol. 6; 1983.

46. Gebel T. Arsenic and antimony: comparative approach on mechanistic toxicology. Chem Biol Interact. 1997;107(3):131-44.

47. Audi G. The NUBASE evaluation of nuclear and decay properties. Nucl Phys A (At Mass Data Cent). 2003;729:3-128. doi:10. 1016/j.nuclphysa.2003.11.001. Bibcode 2003 NuPhA.729....3A.

48.• Ghosh D, Bhadury P, Routh J. Diversity of arsenite oxidising bacterial communities in arsenic rich deltaic aquifers in West Bengal, India. Front Microbiol. 2014;602:1-14. doi:10.3389/ fmicb.2014.00602. Arsenite oxidizing bacterial groups plays a crucial role in geochemical cycling of As in groundwater to sediments. The presence of such microbial population and their diversity in Bengal Delta Plain (India), had been first reported in this paper.

49. Ghurye G, Clifford D. Laboratory study on the oxidation of As III to As V. Proceedings, AWWA Water Quality Technology Conference; 2000

50. Girard J. Principles of environmental chemistry. Jones \& Bartlett Learning. ISBN 9780763759391; 2010.

51. Glick BR. Phytoremediation: synergistic use of plants and bacteria to clean up the environment. Biotechnol Adv. 2003;21(5):383-93. doi:10.1016/S0734-9750(03)00055-7.

52. Gong G, Hargrave KA, Hobson V, Spallholz J, Boylan M, Lefforge D, et al. Low-level groundwater arsenic exposure impacts cognition: a project FRONTIER study. J Environ Health. 2011;74(2):16-22.

53. Government of India Planning Commission Yojana Bhavan New Delhi. Report of the task force on formulating action plan for removal of arsenic contamination in West Bengal. 2007.

54. Halim MA, Majumder RK, Nessa SA, Hiroshiro Y, Uddin MJ, Rahman SH, et al. Hydrogeochemistry and arsenic contamination of groundwater in the Ganges Delta Plain, Bangladesh. J Hazard Mater. 2009;164:1335-45.

55. Harvey CF. Arsenic in groundwater in Bangladesh: a geostatistical and epidemiological framework for evaluating health effects and potential remedies. Water Resour Res. 2003;39:1146-62. doi:10. 1029/2002WR001327.

56. Hayes KF, Traina SJ. Metal ion speciation and its significance in ecosystem health. In: Soil chemistry and ecosystem health, Special Publication No. 52. Soil Science Society America, Madison, WI; 1998.

57. Heaton ACP, Rugh CL, Wang N, Meagher RB. Phytoremediation of mercury and methyl mercury-polluted soils using genetically engineered plants. J Soil Contam. 1998;7:497-510.

58. Heikens A. Arsenic contamination of irrigation water, soil and crops in Bangladesh: risk implications for sustainable agriculture and food safety in Asia. UN FAO report. 2006. 1-46.

59. Hering JG, Chen PY, Wilkie JA, Elimelech M. Arsenic removal from drinking water during coagulation. J Environ Eng. 1997;123(8):800-7.

60. Hood RD. Cacodylic acid: agricultural uses, biologic effects, and environmental fate. VA Monogr. 1985;171.

61. Hopenhayn C. Arsenic in drinking water: impact on human health. Elements. 2006;2:103-7. doi:10.2113/gselements.2.2.103.

62. Hossain M, Anawar HM, Yoshioka T, Konohira E, Akai J, Freitas $\mathrm{MC}$, et al. Sources of organic carbon and depositional environment in the Bengal delta plain sediments during the Holocene period. Limnology. 2010;11:133-42. doi:10.1007/s10201-0090301-9.

63. Hossain M, Bhattacharya P, Frape SK, Jacks G, Islam MM, Rahman MM, et al. Sediment color tool for targeting arsenicsafe aquifers for the installation of shallow drinking water tubewells. Sci Total Environ. 2014;493:615-25. 
64. http://www.cgwb.gov.in/documents/papers/incidpapers/Paper\% 208\%20-\%20Ghosh.pdf [Accessed 07/11/2013]

65. Huang YL, Hsueh YM, Huang YK, Yip PK, Yang MH, Chen CJ. Urinary arsenic methylation capability and carotid atherosclerosis risk in subjects living in arsenicosis-hyperendemic areas in southwestern Taiwan. Sci Total Environ. 2009;407(8):2608-14.

66. IARC (International Agency for Research on Cancer). A review of human carcinogens: arsenic, metals, fibres, and dusts. Lyon: World Health Organization Press; 2012

67. Jahan I, Hoque S, Ullah SM, Kibria MG. Effects of arsenic on some growth parameters of rice plant. Dhaka Univ J Biol Sci. 2003;12:71-7.

68. Johnston R, Heijnen H. Safe water technology for arsenic removal. In: Ahmed MF et al., editors. Technologies for arsenic removal from drinking water. Dhaka: Bangladesh University of Engineering and Technology; 2001.

69. Kaise T, Fukui S. The chemical form and acute toxicity of arsenic compounds in marine organisms. Appl Organomet Chem. 1992;6(2):155-60.

70. Kang LJ, Li XD, Liu JH, Zhang XY. The effect of arsenic on the growth of rice and residues in a loam paddy soil. J Jilin Agric Univ. 1996;18:58-61.

71. Kern RA, Schlesinger WH. Carbon stores in vegetation. Nature. 1992;357:447-8.

72. Kossoff D, Hudson-Edwards KA. Arsenic in the environment Chapter 1. In: Santini JM, Ward SM, editors. The metabolism of arsenite, Arsenic in the Environment, vol. 5. London: CRC Press; 2012. p. 1-23.

73. Ma LQ, Komart KM, Tu C, Zhang W, Cai Y. A fern that hyperaccumulates arsenic. Nature. 2001;409:579.

74. Machlis L. Accumulation of arsenic in shoots of sudangrass and bushbean. Plant Physiol. 1941;16:521-43.

75. Mallick S, Rajagopal NR. Groundwater development in the arsenic-affected alluvial belt of West Bengal-some questions. Curr Sci. 1996;70:956-8.

76. Mandal BK, Chowdhury TR, Samanta G, Mukherjee D, Chanda $\mathrm{CR}$, Saha KC, et al. Impact of safe water for drinking on five families for 2 years in West Bengal, India. Sci Total Environ. 1998;218:185-201

77. Marin AR, Masscheleyn PH, Patrick Jr WH. The influence of chemical form and concentration of arsenic on rice growth and tissue arsenic concentration. Plant Soil. 1992;139:175-83.

78. Marin AR, Pezeshki SR, Masscheleyn PH, Choi HS. Effect of dimethylarsinic acid (DMAA) on growth, tissue arsenic and photosynthesis of rice plants. J Plant Nutr. 1993;16:865-80.

79. Masscheleyn PH, Delaune RD, Patrick WH. Effect of redox potential and $\mathrm{pH}$ on arsenic speciation and solubility in a contaminated soil. Environ Sci Technol. 1991;25:1414-8.

80. McArthur JM, Ravenscroft P, Banerjee DM, Milsom J, Hudson Edwards KA, Sengupta S, et al. How paleosols influence groundwater flow and arsenic pollution: a model from the Bengal Basin and its worldwide implication. Water Resour Res. 2008;44, W11411.

81. McArthur JM, Ravenscroft P, Safiulla S, Thirlwall MF. Arsenic in groundwater: testing pollution mechanisms for sedimentary aquifers in Bangladesh. Water Resour Res. 2001;37:109-17.

82. McBride BS, Wolfe RS. Biosynthesis of dimethylarsine by Methanobacterium. Biochemistry. 1971;10:4312-7.

83. Nakamura K. Biomimetic and bio-inspired catalytic system for arsenic detoxification: bio-inspired catalysts with vitamin-B12 cofactor, on biomimetics, Dr. Lilyana Pramatarova (Ed.). INTECH. 2011. doi:10.5772/19616. ISBN: 978-953-307-271-5.

84. NAS. Arsenic. Natl Acad Sci. Washington, D.C. 1977; 332.

85. Nath B, Berner Z, Chatterjee D, BasuMallik S, Stueben D. Mobility of arsenic in West Bengal aquifers conducting low and high groundwater arsenic. Part II: comparative geochemical profile and leaching study. Appl Geochem. 2008;23:996-1011.

86. Program NT. Report on carcinogens. 12th ed. Research Triangle Park: NTP; 2011.

87. Nickson RT, McArthur JM, Burgess WG, Ahmed KM, Ravenscroft P, Rahman M. Arsenic poisoning of Bangladesh groundwater. Nature. 1998;395:338.

88. Nickson RT, McArthur JM, Ravenscroft P, Burgess WG, Ahmed $\mathrm{KM}$. Mechanism of arsenic release to groundwater, Bangladesh and West Bengal. Appl Geochem. 2000;15:403-13.

89. Norman NC. Chemistry of arsenic, antimony and bismuth (http:// books. google. com/ ?id=vVhpurkfeN4C). Springer. pp. 50. ISBN 9780751403893; 1998.

90. Oremland RS, Stolz JF. Arsenic microbes and contaminated aquifers. Trends Microbiol. 2005;13:45-9. doi:10.1016/j.tim.2004.12. 002.

91. Pandey VC, Singh JS, Singh RP, Wingh N, Yunus M. Arsenic hazards in coal fly ash and its fate in Indian scenario. Resour Conserv Recycl. 2011;55:819-35.

92. Patel KS, Shrivas K, Brandt R, Jakubowski N, Corns W, Hoffmann P. Arsenic contamination in water, soil, sediment and rice of central India. Environ Geochem Health. 2005;27:131-45.

93. Planning Commission. Report of the task force on formulating action plan for removal of arsenic contamination in West Bengal. New Delhi; 2007.

94. Pershagen G, Vahter M. Arsenic - a toxicological and epidemiological appraisal. Naturvardsverket Rapp. 1979;1128:0346-7309.

95. Pittet D, Mourouga P, Perneger TV. Compliance with handwashing in a teaching hospital. Infection control program. Ann Intern Med. 1999;130(2):126-30.

96. Plant JA, Kinniburgh DG, Smedley PL, Fordyce FM, Klinck BA. Arsenic and selenium. Treatise Geochem Elsevier. 2007;9(02): $17-66$.

97. Postma D, Larsen F, Minh Hue NT, Thanh Duc M, Viet PH, Nhan $\mathrm{PQ}$, et al. Arsenic in groundwater of the Red River floodplain, Vietnam: controlling geochemical processes and reactive transport modeling. Geochim Cosmochim Acta. 2007;71:5054-71.

98. Rahman MM, Chowdhury UK, Mukherjee SC, Mondal BK, Paul $\mathrm{K}$, Lodh D, et al. Chronic arsenic toxicity in Bangladesh and West Bengal, India- a review and commentary. Clin Toxicol. 2001;39(7):683-700.

99. Raskin I, Ensley D. Phytoremediation of toxic metals: using plants to clean up the environment. New York: John Wiley and Sons; 2000.

100. Ravenscroft P, Burgess WG, Ahmed KM, Burren M, Perrin J. Arsenic in groundwater of the Bengal Basin, Bangladesh: distribution, field relations, and hydrogeological setting. Hydrogeol J. 2005; 13:727-51.

101. Ravenscroft P, McArthur JM, Hoque BA. Geochemical and palaeohydrological controls on pollution of groundwater by arsenic. Arsenic Expo Health Eff. 2001;IV:53-78.

102. Robertson ID, Harms WE, Ketterer PJ. Accidental arsenical toxicity of cattle. Aust Vet J. 1984;61:366-7.

103. Roychowdhury T, Basu GK, Mandal BK, Biswas BK, Chowdhury UK, Chanda CR, et al. Arsenic poisoning in the Ganges delta. Nature. 1999;401:545-6.

104. Sailo L, Mahanta C. Arsenic mobilization in the Brahmaputra plains of Assam: groundwater and sedimentary controls. Environ Monit Assess. 2014;186(10):6805-20.

105. Selby LA, Case AA, Osweiler GD, Hages HM. Epidemiology and toxicology of arsenic poisoning in domestic animals. Environ Health Perspect. 1977;19:183-9.

106. Sharma VK, Sohn M. Aquatic arsenic: toxicity, speciation, transformations, and remediation. Environ Int. 2009;35:743-59.

107.• Shrivastava A, Barla A, Yadav H, Bose S. Arsenic contamination in shallow groundwater and agricultural soil of Chakdaha block, 
West Bengal, India. Front Environ Sci. 2014;2:50. doi:10.3389/ fenvs.2014.00050. The detailed field study on the arsenic contamination of soil of Bengal Delta Plain (India), had been first reported in this paper. In the areas with long history of use of arsenic elevated groundwater for irrigation in winter, the agricultural lands have been affected severely with arsenic, up to $54 \mathrm{mg} / \mathrm{kg}$.

108.• Singh S, Barla A, Shrivastava A, Bose S. Interplay of arsenic alteration in plant, soil and water: Distribution, contamination and remediation. Glob J Multidiscip Stud. 2014;3: 11. ISSN 2348-0459. Rice plants accumulate arsenic in different parts of their body and thus sometimes show phytotoxicity.

109.• Singh S, Barla A, Srivastava A, Bose S. Isolation of arsenic resistant bacteria from Bengal Delta sediments and their efficiency in arsenic removal from soil in association with Pteris vittata. Geomicrobiology. 2015. doi:10.1080/01490451.2015.1004141. The bacterial strains isolated from the rhizospheric zone of rice plant made the arsenic in bio-available for uptake by Pteris vitata when the plant and bacterial strains were cultivated in closed association for the rapid, inexpensive and environment friendly bioremediation of arsenic contaminated soil.

110. Singh A, Bhardwaj BD. Fluvial facies model of the Ganga river sediments, India. Sediment Geol. 1991;72:135-46.

111. Smedley PL, Kinniburgh DG. A review of the source, behavior and distribution of arsenic in natural waters. Appl Geochem. 2002;17:517-68.

112. Smith E, Naidu R, Alston AM. Arsenic in the soil environment: a review. Adv Agron. 1998;64:149-95.

113. Smith MMH, Hore T, Chakraborty P, Chakraborty DK, Savarimuthu X, Smith AH. A dugwell program to provide arsenic-safe water in West Bengal, India: preliminary results. J Environ Sci Health. 2003;A38(1):289-99.

114. Smith E, Naidu R. Distribution and nature of arsenic along former railway corridors of South Australia. Sci Total Environ. 2004;363(1-3):175-82.

115. Somani SM. Chemical warfare agents: toxicity at low levels. CRC Press. ISBN 9780849308727; 2001.

116. Srivastava S, Sharma YK. Arsenic occurrence and accumulation in soil and water of eastern districts of Uttar Pradesh, India. Environ Monit Assess. 2012. doi:10.1007/s10661-012-2920-6.

117. Sun WJ, Sierra-Alvarez R, Milner L, Field JA. Anoxic oxidation of arsenite linked to chlorate reduction. Appl Environ Microbiol. 2010;76:6804-11. doi:10.1128/AEM. 00734-10.

118. Takahashi Y, Minamikawa R, Hattori KH, Kurishima K, Kihou N, Yuita K. Arsenic behavior in paddy fields during the cycle of flooded and non-flooded periods. Environ Sci Technol. 2004;38: $1038-44$.

119. Tamaki S, Frankenberger WT. Environmental biochemistry of arsenic. Rev Environ Contam Toxicol. 1992;124:79-110.

120. Thatcher CD, Meldrum JB, Wikse SE, Whittier WD. Arsenic toxicosis and suspected chromium toxicosis in a herd of cattle. $\mathrm{J}$ Am Vet Med Assoc. 1985;187:179-82.
121. Tu C, Ma L. Effects of arsenic concentration and forms on arsenic uptake by the hyperaccumulator ladder brake. J Environ Qual. 2002;31:641-7.

122. Turpeinen R, Pantsar-Kallio M, Kairesalo T. Role of microbes in controlling the speciation of arsenic and production of arsines in contaminated soils. Sci Total Environ. 2001;285:133-45.

123. Turpeinen R, Kallio MP, Kairesalo T. Role of microbes in controlling the speciation of arsenic and production of arsines in contaminated soils. Sci Total Environ. 2002;285(1-3):133-45.

124. UNICEF. Arsenic primer guidance for UNICEF country offices on the investigation and mitigation of arsenic contamination. New York; 2008.

125. United States Environmental Protection Agency (U.S. EPA).An exposure and risk assessment for arsenic. Washington, DC: Office of Water Regulations and Standards. U.S. EPA; EPA-440/4-85$005 ; 1982$.

126. Valls M, Lorenzo VD. Exploiting the genetic and biochemical capacities of bacteria for the remediation of heavy metal pollution. FEMS Microbiol Rev. 2002;26(4):327-38.

127. Vaughan GT. The environmental chemistry and fate of arsenical pesticides in cattle tick dip sites and banana plantations. CSIRO, Division of Coal and Energy Technology Centre for Advanced Report Chemistry. Investigation CET / LHIRI 148, Sydney, Australia; 1993.

128. Walsh LM, Sumner ME, Keeney R. Occurrence and distribution of arsenic in soils and plants. Environ Health Perspect. 1977;19: $67-71$.

129. Wenzel WW, Adriano DC, Salt D, Smith R. Phytoremediation: a plant-microbe based remediation system. In: Adriano DC et al., editors. Bioremediation of contaminated soils. Madison: American Society of Agronomy; 1999. p. 457-508.

130. WHO. Guidelines for drinking-water quality, addendum to volume 1: recommendations. Geneva; 1998.

131. Wolfe-Simon F, Blum JS, Kulp TR, Gordon GW, Hoeft SE, PettRidge J, et al. A bacterium that can grow by using arsenic instead of phosphorus. Science. 2010;332(6034):1163-6.

132. Woolson EA (ed.). Arsenical pesticides. Am Chem Soc Symp Ser. 1975;7:176.

133. Woolson EA. Fate of arsenicals in different environmental substrates. Environ Health Perspect. 1977;19:73-81.

134. Yang LS, Peterson PJ, Williams WP, Wang WY, Hou SF, Tan JA. The relationship between exposure to arsenic concentrations in drinking water and the development of skin lesions in farmers from Inner Mongolia, China. Environ Geochem Health. 2002;24:293-303.

135. Yu WH, Harvey CM, Harvey CF. Arsenic in groundwater in Bangladesh: a geostatistical and epidemiological framework for evaluating health effects and potential remedies. Water Resour Res. 2003;39:1146-62. doi:10.1029/2002WR001327.

136. Zhao EJ, Ma JF, Meharg AA, McGrath SP. Arsenic uptake and metabolism in plants. New Phytol. 2009;181(4):777-94. 